\title{
It Offshoring And E_Business Adoption In Iraq: Study From Smes Perspective
}

\section{Abdulniser Khald Hamzah ${ }^{1 *},{ }^{2}$ Waleed Noori Hussein ${ }^{3}$ Ali Abdul Kadhim Ruhaima}

${ }^{1}$ Corresponding E-mail: nasernaser310@ gmail.com

Department of Computer Engineering TechniquesAl-Nisour University Baghdad,Iraq

2Email: waleed.hussein@uobasrah.edu.iq

University of Basrah, AL-Zahraa College of Medicine

3Ali.abd.eng@nuc.edu.iq

Department of Computer Engineering TechniquesAl-Nisour University Baghdad,Iraq

Article History: Received:11 January 2021; Accepted: 27 February 2021; Published online: 5 April 2021

Abstract: The aims of this research were to investigate the factors that influence the IT offshoring approach among the Iraqian SMEs and whether this approach can be considered for the SMEs e_business implementation. SMEs face many issues such as technological, business, economic and cultural nature, while trying to be in an advantage edge or survive at least. Business offshoring is one of the approaches common especially in IT development to assist the enterprises to automate and streamline the business processes. This research applied the quantitative and qualitative approaches when collecting data from the Iraqiann SMEs. SPSS software was used to analyse the collected data.

Keywords: SMEs, E_business, IT offshoring, IT offshoring success factors.

\section{INTRODUCTION}

One of the recognised potential areas in Iraq is business services, especially in involving IT offshoring services [1, 2]. In general, the practices of IT offshoring are being adopted frequently by large local and multi-national companies[3]. Nevertheless, the practices for SMEs are still limited to non-core processes and general office automation [4]. The needs for SMEs is created when the situation of business be further dynamic and moves to e_business, to improve their effectiveness by spreading their services, for example, storage, data farm, and front and back-end applications. Corresponding to the Iraqian Economic Transformation Plan, SMEs should globally reach customers through e_business [1]. Nevertheless, at present only $20 \%$ of the 700,000 SMEs have websites [5].

Because of the limitations of SMEs, for instance, awareness lack, and rare resources in capital and manpower to improve IT application; becoming a full-fledged e_business has not been prioritized. Nevertheless, SMEs can compete globally and move forward. Thus, the solution for this problem could be the IT offshoring. Companies use e_business for improving their business trade opportunities and novel markets; and by rising their sales they tend to shrink their transaction cost, beside, the increase the cooperating flexibility with business partners [6].

E_business is highly affecting the implementation of business processes; it also improves the industries structure, and eliminates the power balance between the enterprises and their suppliers and customers.

In business, enterprises have to assess the opportunities and threats presented by e_business. The internet has driven new financial environment, by creating unique opportunities for enterprises, individuals, and countries [7]. In the past decade, the area of IT offshoring faced many failures [8, 9]. Nevertheless, there is still a lack of researches in identifying the parameters that impact the successful offshoring accomplishments. Previous researchers have failed to recognize the parameters that inhibit or influence IT-offshoring [10], accordingly, a very large research gap has showed, and whether IT-offshoring will succeed or fail is an question remained unanswered.

As a fact, many researches and unlimited resources are needed to be able to evaluate and study all the aspects related to successful IT offshoring; as whether IT offshoring will succeed or not is still not proven yet. Nevertheless, this research have identified some factors to be studied and measured.

\section{IT OFFSHORING}

Over these years, companies have used IT offshoring as an approach for shrinking their costs [11, 12]. Besides, IT offshoring has become significant, because of the management pressure, intended establishing the enterprise boundaries, besides, to a growing recognition of the possible advantages, that may be gained from closer collaboration between the enterprise and the service provider $[13,14]$. 
Based on these facts, this present study has recognized that, there is a need to investigate the determinants of success in terms of IT offshoring in a SMEs.

The use of offshoring as a part of the general strategy has become more popular over the time. Furthermore, offshoring could be a short cut to gain useful skills and knowledge in a short term perspective[15]. According to Kessler, Bierly [16], an organization could establish a strategic partnership to gain access to skills and knowledge that could make them more competitive. One objective with the use of offshoring is to get access to some of those competencies, which an organization requires for its operations; so that, an organization gets an opportunity to focus on its core competencies instead, this is the actual source for creating a competitive advantage [17]. The decision to use offshoring as a part of an overall strategy could be rather controversial.

Major companies offshore IT-services focused on their core business activities, and recognize their benefits behind offshore IT services to third party.

The most usual IT services offshoring take account of software development, data/information processing, maintenance, and system hosting.

\section{E_BUSINESS PRACTICES IN SMEs}

Generally, previous studies have focused on the difference among SME's and large companies, in terms of the contribution of e_business, particularly on the SME's side [18-20]. On the other hand, both, SME's and large companies share some mutual goals, for instance, stability and long-term profit, etc., all these goals encourage the companies to adapt new methodologies or efficient approaches for enhancing the business process. According to Taylor and Murphy [21] SME's have been trying to succeed on achieving this by less number of resources, and by the strong impact from the owners or the decision makers [22].

Furthermore, in developing countries, the awareness and adoption of e_business in SME's have been motivated by markets more than the western countries [23]. E_business technologies have been adapted by SME's as a strategic plan, for smoothing the variances with the big players, or getting an edge advantage over them, for example, obtaining a competitive advantage or improving service quality. One of the most important share between western and developing countries is the requirement to exchange information and knowledge among SME's and their partners all over the world, in an electronic platform [24, 25].

SME's extremely vary in the degree of adopting e_business technologies, both, globally or even smaller regions. According to Wimmer, Bogataj [26], it is significant to know that, SME and e_business are assumed rather differently by various researchers and investigators, so exacting one-to-one evaluations are not all the time feasible or meaningful. There are many motivations for IT internationalization of SMEs. However, the core motivations recognized, while working with different companies in the field are: following customers or partners to a new markets, the wish of exploiting comparative advantages, economies of scale and scope, human resource seeking (e.g. analysts, developers, project managers), diversification of the markets, market seeking, experience and information seeking, excess production capabilities available, small local market, owner's ambitions moreover, previous experience in international markets, and manager's competence.

According to Han, Lee [27], adopting e_business in the supply chain carries a lot of profits to enterprises, recently, researches illustrate that, numerous SMEs have not yet applied e_business. SMEs are deliberate to be a crucial element for the economic development of the countries [28].

Nevertheless, SMEs are furthermore affected by a competitive pressure from various countries, such as, India, China, and Vietnam. Enterprises in such countries have a lower labour costs, than in Iraq. Thus, to compete with enterprises from these countries, the Iraqian SMEs have to perform effectively. One approach to reach that is to have an effective supply chain over implementing e_business technologies [29].

\section{IT OFFSHORING SUCCESS FACTORS}

Many IT offshoring success parameters have already gained attention in the literature [9, 30-32]; nevertheless, this present research differs from the previous ones, by focusing on combining three dimensions: relationship, contract and capability, and measure their influence on successful IT offshoring. Business executives were involved, in order to provide their vision regarding to IT offshoring in the literature. The author has reviewed and analysed many models, and identified each model and the specific influencing factors that shows in table 1.

After reviewing these IT offshoring models, the table 1 shows that, the majority of the researchers use trust as a determinant for IT offshoring in their models. Furthermore, several models have revealed that, trust has been frequently used as a determinant for relationship among partners $[33,34]$. In this, context this study has considered 
trust as an important factor, since it also affects the relationship between the partners. Consequently, commitment is another factor that has been used frequently in many models (see table 1).

According to table 1, there is a lack of research towards information sharing in the previous studies on IT offshoring. Therefore, information sharing has been considered as an important factor affecting the partnership quality of offshoring [35]. The client-vendor relationship critically affect the success or failure of the offshoring arrangement [35].

A way to reach profits from IT offshoring is through sustaining positive client to vendor relationship [36]. Constructing and maintaining a sufficient clients-vendors relationship of IT offshoring initiatives is a way to add values from offshoring [37]. Relationship understanding that grows in IT offshoring is critical, as it comes not only through the contract operationalization, but further as a normal significance of the issues, resulting due to dependency. Besides the collective practice of IT offshoring, the offshoring nature has moved from a pure contractual, to the one, based on relationship [35]. According to these facts, trust and commitment are important factors for building a satisfactory model for successful IT offshoring. This paper has investigated the relationship between each of these two factors and the success of IT offshoring.

Moreover, the literature shows that, completeness of contract has been highly recommended as a determinant for IT offshoring [38]. Consequently, Handley and Benton Jr [39] have found that, completeness of contract is important in determining the performance of IT offshoring. Furthermore, the model proposed by Blumenberg, Beimborn [40]shows that, completeness of contract affects the success of the relationship between partners.

Table 1: Reviewing of determining factors that influencing offshoring

\begin{tabular}{|c|c|c|c|c|c|c|c|c|c|c|c|c|c|}
\hline \multirow[b]{2}{*}{ Authors } & \multicolumn{13}{|c|}{ Factors } \\
\hline & $\overrightarrow{\underline{w}}$ & 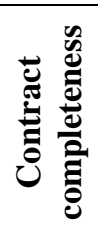 & 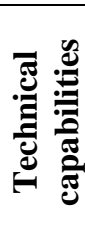 & 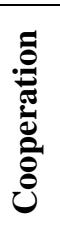 & 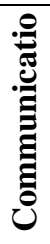 & 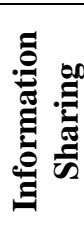 & 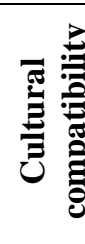 & Uِ & 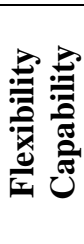 & 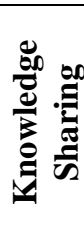 & 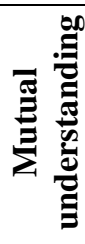 & 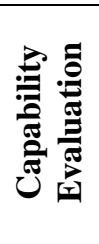 & 葛 \\
\hline [39] & & $\sqrt{ }$ & & $\sqrt{ }$ & & & & & & & & & $\sqrt{ }$ \\
\hline [33] & $\sqrt{ }$ & & & & & & & & & & & & $\sqrt{ }$ \\
\hline [35] & $\sqrt{ }$ & & & $\sqrt{ }$ & $\sqrt{ }$ & $\sqrt{ }$ & $\sqrt{ }$ & & $\sqrt{ }$ & & & & \\
\hline [41] & $\sqrt{ }$ & & & $\sqrt{ }$ & $\sqrt{ }$ & & & & & & & & $\sqrt{ }$ \\
\hline [40] & $\sqrt{ }$ & $\sqrt{ }$ & & & $\sqrt{ }$ & & $\sqrt{ }$ & & & $\sqrt{ }$ & $\sqrt{ }$ & & $\sqrt{ }$ \\
\hline [42] & & & & & $\sqrt{ }$ & & & & & & & & \\
\hline [36] & & & & & & & & & & & & $\sqrt{ }$ & \\
\hline [38] & & & & & & & & & & & & & $\sqrt{ }$ \\
\hline [36] & $\sqrt{ }$ & & & $\sqrt{ }$ & $\sqrt{ }$ & & & & & & & & $\sqrt{ }$ \\
\hline [43] & $\sqrt{ }$ & & $\sqrt{ }$ & & & & & & & & & & $\sqrt{ }$ \\
\hline [44] & & $\sqrt{ }$ & & & & & & & & & & & \\
\hline [45] & $\sqrt{ }$ & & & & & & & & & & & & \\
\hline [46] & & & $\sqrt{ }$ & & & & & & & & & & \\
\hline [47] & $\sqrt{ }$ & & & & & & & $\sqrt{ }$ & & & & & $\sqrt{ }$ \\
\hline
\end{tabular}




\begin{tabular}{|l|c|l|l|l|l|l|l|l|l|l|l|l|l|}
\hline$[37]$ & $\sqrt{ }$ & & & & & & & & & $\sqrt{ }$ & & \\
\hline$[22]$ & $\sqrt{ }$ & & $\sqrt{ }$ & & $\sqrt{ }$ & $\sqrt{ }$ & & & & $\sqrt{ }$ & & & $\sqrt{ }$ \\
\hline
\end{tabular}

Subsequently, Chan [43] has showed that, the internal technical capability for the organization is an important issue related to IT offshoring. By reviewing the dimension of the capabilities for the organization, technical capability has been found essential for IT offshoring initiatives [46]. The literature shows a lack of measuring the effect of internal technical capabilities in the success of IT offshoring. Furthermore, few previous studies have considered cultural compatibility as a factor determining relationship between partners[35].

To construct the model we need to narrow down the area that represent the major indicators, metrics, and determinants of IT offshoring from the point of view of buyer company.

As the approach of this study is to discover the crucial factors that the enterprises are required while having an IT offshoring

preparations, this research went through various sources. The following table shows

the determinants gathered from previous literatures and analysed to formulate the factors, focused by several researchers; some specific factors that have been focused in this research, and their data collection methods, sample size, what to measure, region and if it covers SMEs or not have been presented. Table 2shows that, several researchers have studied the choosing factors, which have been extracted from table 1; the specific researches in this table have used different data collection methods and different sample size. This table has also showed the variable that has been measured by the determinants of each research. It has also specified the region of the research and if it has covered SMEs or covered organizations in general.

Table 2: Reviewing of choosing factors in the literature of IT offshoring

\begin{tabular}{|c|c|c|c|c|c|c|c|c|c|c|c|}
\hline $\begin{array}{c}\text { Prior } \\
\text { Studies }\end{array}$ & 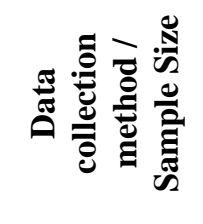 & $\vec{E}$ & 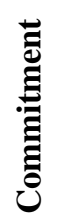 & 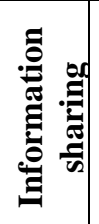 & 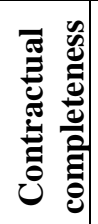 & 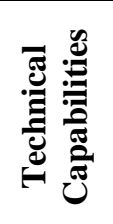 & 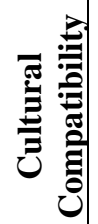 & 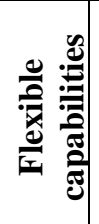 & 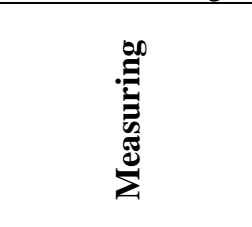 & 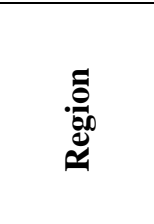 & 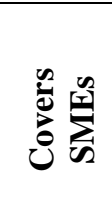 \\
\hline [48] & $\begin{array}{c}\text { Interview } \\
2 \text { Case study }\end{array}$ & $\sqrt{ }$ & $\sqrt{ }$ & & & & & & $\begin{array}{c}\text { Successful IT } \\
\text { offshoring }\end{array}$ & China & No \\
\hline [33] & Survey (93) & $\sqrt{ }$ & $\sqrt{ }$ & & & & & & $\begin{array}{c}\text { Partnership } \\
\text { Quality }\end{array}$ & Korea & No \\
\hline [35] & $\begin{array}{c}\text { Survey \& } \\
\text { interviews (1 } \\
\text { case study) }\end{array}$ & $\sqrt{ }$ & $\sqrt{ }$ & & & & $\sqrt{ }$ & $\sqrt{ }$ & ITO relationship & Korea & Partial \\
\hline [41] & $\begin{array}{l}\text { Survey \& } \\
\text { case study }\end{array}$ & $\sqrt{ }$ & $\sqrt{ }$ & & & & & & $\begin{array}{l}\text { IT offshoring } \\
\text { relationship }\end{array}$ & Iraqian & No \\
\hline [40] & $\begin{array}{c}\text { Interview\& } \\
\text { survey } \\
(1000)\end{array}$ & $\sqrt{ }$ & $\sqrt{ }$ & & $\sqrt{ }$ & & & & $\begin{array}{l}\text { Relationship } \\
\text { Quality }\end{array}$ & General & No \\
\hline [38] & Survey (92) & & $\sqrt{ }$ & & $\sqrt{ }$ & & & & $\begin{array}{l}\text { IT offshoring } \\
\text { success }\end{array}$ & General & No \\
\hline [36] & $\begin{array}{l}\text { Online } \\
\text { Survey }\end{array}$ & $\sqrt{ }$ & $\sqrt{ }$ & & $\sqrt{ }$ & & & & $\begin{array}{l}\text { IT offshoring } \\
\text { success }\end{array}$ & General & No \\
\hline [43] & 3 Case study & $\sqrt{ }$ & $\sqrt{ }$ & & & & & & $\begin{array}{l}\text { IT offshoring } \\
\text { success }\end{array}$ & General & No \\
\hline [44] & 5 Case study & & & & $\sqrt{ }$ & & & & $\begin{array}{l}\text { IT offshoring } \\
\text { success }\end{array}$ & General & No \\
\hline [46] & Survey (122) & & & & & $\sqrt{ }$ & & & $\begin{array}{l}\text { IT offshoring } \\
\text { success }\end{array}$ & $\begin{array}{c}\text { China } \\
\text { and India }\end{array}$ & No \\
\hline [37] & Survey (267) & $\sqrt{ }$ & & & & & & & $\begin{array}{l}\text { IT offshoring } \\
\text { success }\end{array}$ & Korea & No \\
\hline [22] & Survey (198) & $\sqrt{ }$ & $\sqrt{ }$ & & & $\sqrt{ }$ & & & $\begin{array}{l}\text { IT offshoring } \\
\text { success }\end{array}$ & General & No \\
\hline
\end{tabular}


As shown in Table 1, many previous researchers have studied the factors related to IT offshoring in the literature. However, the table 2 has consequently focused on the factors that influence success of IT offshoring, performance, relationship quality, and conflict handling. Table 2 differentiates these researches, to show their significance. This table represents that, most of the models emphasis on trust as an important factor to determine IT success of offshoring, performance and relationship.

\section{RESEARCH METHODOLOGY}

Qualitative and quantitative approaches are interactive by involving interviews and structured questionnaire in this research. The strategy of this study was used to have a depth and breadth of this study specially within the process of data collection [49]. The approach of qualitative study was selected for this research to recognizing IT offshoring services, key success factors, and potentials in-depth among SMEs in Iraq.

This required interviews and observation of SMEs common practices with respect to IT offshoring practices. For quantitative approach, a survey technique was used to have more respondents that can contribute to this research. The outcome of this study is an IT offshoring integrated framework for Iraqiann SMEs to be used together with their E_business initiatives.

This research will examine and identify the potential of IT offshoring in E_business for SMEs, the research also will analyze and evaluate three previous models for offshoring and developing a new model. In additional, the survey will be distributed to conduct the results and analyze it. Therefore a mixed mode of qualitative and quantitative is appropriate for this research. In this research, the scale questions have been used to answer the questions that related to evaluate the influence of the factors. A summary of Item's description, frequency and sources shown in table 5.

\section{Hypotheses Development}

This section covers comprehensive discussions on key relationships in the model and their related hypotheses. The first part presents the hypotheses related to relationship dimension, and the IT offshoring success that have been derived in this research. The second part presents the hypotheses related to contract dimension and IT offshoring success. Moreover, the third section first shows the hypothesis associated with internal technical capabilities and IT offshoring success, and second presents the hypothesis related to cultural compatibility and IT offshoring success, and finally presents the hypothesis related to cultural compatibility and IT offshoring success.

Offshoring success has been gauged by many researchers through measuring a single item such as cost saving [50], and vendor performance [51, 52]. Instead of evaluating cost savings only, Goonetilleke [3] suggested that offshoring success needs to be evaluated from a three perceptions; technical, economic and strategic benefits. Finally, this research viewpoint is to measure IT offshoring success through the three dimensions; relationship, contract and capability dimension.

\subsubsection{Hypotheses related to Relationship Dimension and IT Offshoring Success}

Relationship shows the degree to which the offshoring enterprise are attempt to create and maintain a sustain beneficial relationship with the provider [43]. Many researchers have previously addressed the significance of relationships on the success of IT offshoring, Han, Lee [27] have studied the influence of trust and commitment in the relationships on the IT offshoring success. According to Lee [53] trust affects the way in which inter organization interactions are conducted and organized.

Based on our literature review we have identified that, it is unlikely to involve with minimally interdependent relationships, since it is less related to the functioning of such relationships. On the other hand, interdependent relationships can greatly improve and develop a greater degree of trust. A high interdependence relationship is dangerous for both partners, to involve in adaptable behavior or pressure, since both parties have a lot to lose. These interdependences also improves the power asymmetry between the organization and the provider, and motivate each party to cultivate trust in the partner, because none of the partner can use their non-convergent power to get the cooperation from the other [43]. Consequently, common dependence generates a greater need for trust and motivate for developing it.

Trust in a relationship adopts the theory, which assumes that, the partner will achieve an action that brings positive results, and refrain from involving in unexpected behaviour. As a fact, trust is showed in different direct and indirect manners by researchers, in the relationships environment of IT offshoring. This shows that, it is crucial for the 
companies to reach high degree of trust as a relationship quality measurement, and involve several strategies, behavioral and advices patterns for this goal. This insistence of the enterprises on this parameter has motivated the researchers to take trust as an IT offshoring factor. These imperatives have provided the foundation for hypothesis 1:

Hypothesis 1: Trust positively influences the degree of IT offshoring success

Based on our literature review it is evident that, trust and commitment are interdependent factors in the relationships between the buyers and providers of IT services; the greater commitment leads to greater trust and vice versa [9]. Furthermore, commitment to the sustain relationship can add more efficiency to the enforcement plan, due to the parties that would take the economic and legal consequences, more serious. Thus, the intensity of relationship commitment is associated with IT offshoring success; hence, we have derived the hypothesis 2:

Hypothesis 2: Commitment positively influences the degree of IT offshoring success.

Essential information sharing happens by contractually agreed upon communications, for instance, regular meetings and exchanges [27]. By sharing information both partners are able to behave more efficiently and being knowledgeable partners. Therefore, intense relationship may build a competitive advantage through key information sharing. Consequently, hypothesis 3 has been formulated as follows:

Hypothesis 3: Information sharing positively influences the degree of IT offshoring success

\subsubsection{Hypotheses related to Contract Dimension and IT Offshoring Success}

Formal contracts assist in two main purposes regarding inter-firm exchanges coordination, and control. Nowadays, contracts developed without concerning about the operating environment, are of limited value [39]. A sophisticated understanding of the offshoring strategy's insinuations places the offshoring enterprises in an improved location to create and agree to a contract with more efficient. A deeper evaluation of the risks related to offshoring and the strategic importance of activity of the outsourced business drive to develop a specific contractual provision [54-57]. Contractual completeness is the extent to which the enterprise and the provider develop a contract, which effectively coordinates resources, and addresses identified organizational risks. Thus, the hypothesis 4 has been proposed:

Hypothesis 4: contractual completeness positively influences the degree of IT offshoring success.

\subsubsection{Hypotheses related to Capability Dimension And It Offshoring Success}

In the case of offshoring, the enterprise's critical functions might be moved out of the enterprise due to cost or other considerations; nevertheless, moving out the entire IT department may drive the enterprise to face many risks such as loss of effectiveness [43]. In this context, Grover, Cheon [58] have also declared that an enterprise's previous investments in it's technical abilities might have sustained economic value in the present and future investments, those previous investments could push the enterprise to understand new knowledge and technology more efficiently.

Consequently, it is essential for an enterprise to preserve internal technological capabilities to improve experience and revel in more profits from the offshoring arrangement. Some researches on inter-organizational relationships have considered capability crucial in assuring project success, therefore shows that vendors should have the capability to keep up-to-date with ever changing technologies and maintain higher quality services and relationships [59]. Based on the above discussion the hypothesis 5 has been stated as follows:

Hypothesis 5: Technological capability positively correlated to the level of IT offshoring success.

Cultural compatibility capability refers to the extent to which the partners can coexist with each other's beliefs on behaviours, goals, and policies, values [35, 57]. Furthermore, Blumenberg, Beimborn [40] have discussed that partnership with incompatible organizational cultures create obstacles in inter-organizational relationships in general. In contrast, the relationship between organizations with compatible cultures are more probably successful than the organizations with incompatible cultures [35, 57]. The existence of a cultural compatibility between organizations is believed to improve the relationship quality [40]. Consequently, the hypothesis 6 has been formulated: 
Hypothesis 6: Cultural Compatibility Capability positively influences the level of IT offshoring success.

Flexibility capability, in which flexibility refers to a bilateral expectation of willingness to make adaptations as circumstances change [35, 60]. According to the long-term nature of the arrangements of IT offshoring, it is practically impossible to accurately pre-specify the entire process in detail $[52,61]$. Moreover, to cope with the growing nature of technology, the emergence of competitive services and changing the business environment flexibility is necessary $[35,52,62]$. Therefore, the involved partners need to deal with the possible changes by being flexible. A relationship between parties needs to be able to accommodate changes otherwise it might break down under the pressure generated by the change.

According to Wang and Yang [63], the loss of flexibility increases the complexity of information services management and damages the organization's innovative capability. Hence, flexibility should not be ignored in offshoring activities. Maximizing the flexibility should be one of the main objectives of the organizations involved in IT offshoring processes [2,35]. Additionally, in case of public sector the offshoring, contract is maintained strictly. However, being flexible will seriously improve the quality of the relationship between the partners. Accordingly, the hypothesis 7 has been formulated:

Hypothesis 7: Flexibility Capability positively influences the level of IT offshoring success.

The Table 3 below illustrates the summary of the hypotheses derived in our study based on the extensive literature review.

Table 3: Summary of hypotheses

\section{Hypotheses}

Hypothesis 1: Trust positively influences the level of IT offshoring success

Hypothesis 2: commitment positively influence the level of IT offshoring success

Hypothesis 3: Information sharing positively influences the degree of IT offshoring

success

Hypothesis 4: contractual completeness positively influences the level of IT offshoring success

Hypothesis 5: Technological capability positively influences the level of IT offshoring success.

Hypothesis 6: Cultural compatibility positively influences the level of IT offshoring success.

Hypothesis 7: Flexibility capability positively influences the level of IT offshoring success.

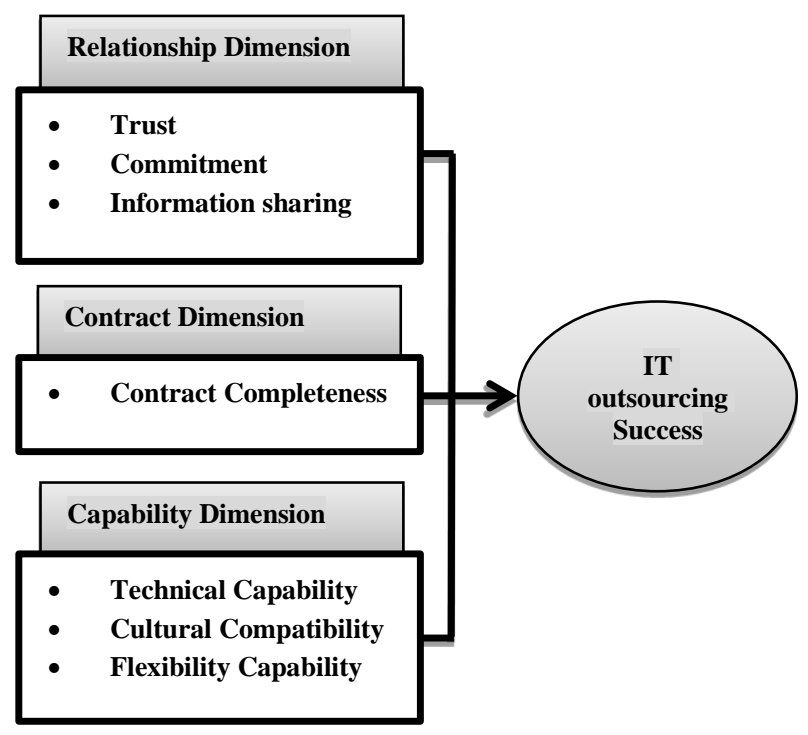

Table 4: The proposed model 


\section{QUESTIONNAIRE DESIGN}

The questionnaire is a well-known technique that many researchers depend on it to collect data and to find answers. This research uses the questionnaire as a resource for its data by the method of structured questions that contain critical questions regarding various characteristics surrounding IT offshoring in e_business among Iraqiann SME's. Questionnaires had to be short, attractive, divided by issue [64]. The questionnaire was sequentially and logically structured as the questions tracked the sequence of the research. For this research, the questionnaire was adapted from many sources as shown in table 5 below. The content of each question was adopted from the critical literature review. The questionnaire consisted of 48 questions, but there is a space in section (A) for the respondent to specify his/her own answer of some questions.

The questionnaire was designed based on two approaches which are paper-based approach and web-based approach. The sample size of a research is a vital consideration, since a large enough sample size makes it possible to generalize the target population, besides have enough statistical power to a confidential results. According to Bless and HigsonSmith [65], the size of the sample is an important element in the research. There were a total of 47,695 SMEs in all over Iraqian according toSMIDEC [66] dictionary official website, a total of 9074 SMEs of them located at Kuala Lampur were be

Table 5: Summary of Items frequency and sources

\begin{tabular}{|c|c|c|c|}
\hline Constructs & Descriptions & Items & Sources \\
\hline Trust & Measuring trust in the relationship between the partners & 4 & $\begin{array}{l}{[37,43,47,67,} \\
68]\end{array}$ \\
\hline Commitment & $\begin{array}{l}\text { Measuring commitment in the relationship between the } \\
\text { partners }\end{array}$ & 4 & {$[27,47]$} \\
\hline Information Sharing & $\begin{array}{l}\text { Measuring the information sharing in the relationship } \\
\text { between partners }\end{array}$ & 3 & {$[27]$} \\
\hline Contract completeness & Measuring completeness contract between the partners & 6 & [39] \\
\hline Internal IT capability & $\begin{array}{l}\text { Measuring the internal Technical IT capability of the } \\
\text { enterprise }\end{array}$ & 3 & {$[27,43]$} \\
\hline $\begin{array}{l}\text { Cultural Compatibility } \\
\text { Capability }\end{array}$ & Measuring the capability of cultural compatibility & 3 & [35] \\
\hline Flexibility Capability & Measuring the flexibility capability & 4 & [35] \\
\hline IT offshoring success & $\begin{array}{l}\text { Strategic, economic, and technological benefits of IT } \\
\text { offshoring }\end{array}$ & 9 & {$[27,37,38,43]$} \\
\hline Checklist question & $\begin{array}{l}\text { Consist of demographic questions and the rest of the } \\
\text { questions related to IT offshoring potentials, services and } \\
\text { providers }\end{array}$ & 12 & {$[42,43,69]$} \\
\hline Total & ---- & 48 & ------ \\
\hline
\end{tabular}

the population of this study. According to Sekaran [70], a sample size of 368 is enough for this population. However, not all of the SMEs that recorded in SMIDEC [66] were putting their full information. Accordingly, the actual respondents for this study were only 113 enterprises, which represent $30.7 \%$ of the total sample size.

\section{DATA ANALYSIS AND RESULTS}

Once collect the required data, the analysis of the collected data the next step. The analysis of the data will include analysing and categorizing the collected data. In this study the data collected from the questionnaire are analyzed quantitatively. In this research, the statistical analysis and data management offshoring software package that will be used is SPSS version 17. Descriptive statistics, correlation, regression and mean tools will be involved to deliberate the results of this research. The analysis will be done by taking the answers from the questionnaires and entered them into SPSS to analyse. Formerly, the questionnaire data have been moved into SPSS, the analyses will then perform.

In this study, it's good to know which sector that each enterprise belongs to, in order to have a clear understanding of SMEs and the sectors that they fills under, which gives this research a knowledge of the SMEs respondents and how they think about IT. The result of (113) respondents for the job title question shows that most of the respondents mention their job titles as a IT employee that represent $35.4 \%$ of the respondents which is 40 participants. Moreover, 
29 of the respondents are Professional which represents $25.7 \%$ of the overall participants. While, there are 25 of the respondents are managers which represent $22.1 \%$

of the participants. We could see that $64.6 \%$ of our total respondent's rate worked within a company with 5 to 19 employees. The second largest group was companies with 20 to 50 employees with a respondents' rate of $30.1 \%$. The remaining six respondents were working within a company with 51 to 150 employees.

Knowing the sizes of the enterprises that has been participated in this survey is very important to achieve the objective of this work. For this research, the sizes of the involved enterprises will help to identify the capabilities, resources and limitations of the enterprises. The results show that the majority of the involved enterprises were small sized, since they chose a number of employees from 5 to 19. The small enterprises suffer from many obstacles such as limited capabilities and resources. After analyzing the data, the next step was testing the proposed determinants model that has been constructed by this study. Testing the model includes examining the factors which involved in this model. Each factor in this model will be evaluated, while showing its relationship degree and influence on IT offshoring success. A significant and positive relationship of any factor in this model will make this factor supported and this will improve its existence in the model, while insignificant factors in this model will be ignored. The supported factors will formulate the new supported determinants model.

\subsection{Descriptive Statistics of Variables}

The descriptive analysis was prepared to measure the dependent and independent variables. The measurements for the overall variables were based on 5-point Likert scale. Mean and standard deviation for each variable were shown in Table 6.

Table 6: Summary of descriptive statistics of variables and items

\begin{tabular}{|c|c|c|}
\hline Item & Mean & $\begin{array}{c}\text { Overall } \\
\text { Mean }\end{array}$ \\
\hline TRUST1 & 4.29 & \multirow[t]{4}{*}{4.24} \\
\hline TRUST2 & 4.23 & \\
\hline TRUST3 & 4.19 & \\
\hline TRUST4 & 4.27 & \\
\hline COMIT1 & 4.26 & \multirow[t]{4}{*}{4.00} \\
\hline COMIT2 & 3.89 & \\
\hline COMIT3 & 3.94 & \\
\hline COMIT4 & 3.93 & \\
\hline INFO1 & 4.03 & \multirow[t]{4}{*}{3.96} \\
\hline INFO2 & 3.96 & \\
\hline INFO3 & 3.96 & \\
\hline INFO4 & 3.98 & \\
\hline CONT1 & 4.06 & \multirow[t]{6}{*}{4.07} \\
\hline CONT2 & 4.01 & \\
\hline CONT3 & 4.02 & \\
\hline CONT4 & 3.99 & \\
\hline CONT5 & 4.18 & \\
\hline CONT6 & 4.19 & \\
\hline TECH1 & 2.27 & \multirow[t]{3}{*}{2.02} \\
\hline TECH2 & 1.92 & \\
\hline TECH3 & 1.87 & \\
\hline CULT1 & 4.03 & \multirow[t]{3}{*}{4.08} \\
\hline CULT2 & 4.14 & \\
\hline CULT3 & 4.08 & \\
\hline FLXI 1 & 4.17 & \multirow[t]{3}{*}{4.17} \\
\hline FLXI2 & 4.18 & \\
\hline FLXI 3 & 4.18 & \\
\hline SUCC1 & 3.89 & 3.94 \\
\hline
\end{tabular}




\begin{tabular}{|c|c|}
\hline SUCC2 & 3.94 \\
\hline SUCC3 & 3.93 \\
\hline SUCC4 & 4.03 \\
\hline SUCC5 & 3.89 \\
\hline SUCC6 & 3.94 \\
\hline SUCC7 & 3.93 \\
\hline SUCC8 & 4.03 \\
\hline SUCC9 & 3.89 \\
\hline
\end{tabular}

The variables have maximum and minimum values equivalent to the extreme scales representing a good spread of the responses.

Table 6 illustrate that, the means of the adoption of e_business among SMEs and IS usage were 3.91 each. The external pressure demonstrates the highest mean of 3.98 while administrative innovation and customers' pressure were 3.90 each. As well, the system innovation shows the mean of 3.93. The means of top management support and knowledge sources were 3.96 and 3.81, respectively. The overall variables were nearly 4 indicating that most respondents agreed that the items corresponded to the

variables. The correlation degree cares about measuring the significance and strength of a relationship between the variables. Pearson's correlation coefficient ( $r$ ) with significance levels was involved to assess the correlations between the variables. Pearson's correlation was applied to show the inter-correlation of independent variables in terms of trust, commitment, information sharing, contract completeness, technological capabilities, cultural compatibility and flexibility capability and dependent variables, which means the IT offshoring success among SMEs. Table 7 shows the Cronbach's alpha and Correlations for the overall variables, as follows:

Table 7: The Correlations and Cronbach's alpha for all variables

\begin{tabular}{|c|l|c|c|c|c|c|c|c|c|}
\hline Items & Factors & 1 & 2 & 3 & 4 & 5 & 6 & 7 & 8 \\
\hline 4 & Trust & $\underline{0.919}$ & & & & & & & \\
\hline 4 & Commitment & $.834^{* *}$ & $\underline{0.740}$ & & & & & & \\
\hline 3 & Information technology & $.872^{* *}$ & $.700^{* *}$ & $\underline{0.707}$ & & & & & \\
\hline 6 & Contract completeness & $.909^{* *}$ & $.832^{* *}$ & $.819^{* *}$ & $\underline{0.824}$ & & & & \\
\hline 3 & Flexibility capability & $.909^{* *}$ & $.791^{* *}$ & $.841^{* *}$ & $.870^{* *}$ & $\underline{0.679}$ & & & \\
\hline 3 & Culture compatibility & $.919^{* *}$ & $.837^{* *}$ & $.810^{* *}$ & $.911^{* *}$ & $.884^{* *}$ & $\underline{0.765}$ & & \\
\hline 4 & $\begin{array}{l}\text { Technological } \\
\text { capability }\end{array}$ & $-.110-$ & $-.062-$ & $-.056-$ & $-.096-$ & $-.071-$ & $-.108-$ & $\underline{0.896}$ & \\
\hline 9 & IT offshoring success & $.768^{* *}$ & $.950^{* *}$ & $.700^{* *}$ & $.783^{* *}$ & $.715^{* *}$ & $.792^{* *}$ & $-.024-$ & $\underline{0.884}$ \\
\hline
\end{tabular}

Notes: $* * p<0.01, * p<0.05$. Underlined diagonal entries are the Cronbach's alpha.

As Table 7 indicates, the technical capabilities showed negative correlation $(r=-.024)$ whereas all other variables showed positive correlation with the dependent variables, as follow; trust $\left(\mathrm{r}=.768^{* *}\right)$, commitment $\left(\mathrm{r}=0.950^{* *}\right)$, information sharing $\left(\mathrm{r}=0.700^{* *}\right)$, contract completeness $\left(\mathrm{r}=0.783^{* *}\right)$, cultural compatibility $(\mathrm{r}=0.792 * *)$ and flexibility capability $\left(\mathrm{r}=0.715^{* *}\right)$. The Cronbach's alpha values of all the study variables were also presented in Table 7. The reliability test shows Cronbach alphas in the range of 0.707 to 0.919 , while the Cronbach alpha for the overall factors is 0.91 .

\subsection{Regression Analysis}

This research was used regression analysis to shows the relationship analyze between different variables as assumed in the hypothesis. Besides, linear regression analysis was calculated in order to test the relationship between trust, commitment, information sharing, contract completeness, technological capabilities, cultural compatibility and flexibility capability (independent variables) and IT offshoring success (dependent variable). The basic assumptions underlying linear regression analyses were inspected, to ascertain the requirements. For all the results the regression results are available in table 8 below. This explains the hypotheses $\mathrm{H} 1, \mathrm{H} 2, \mathrm{H} 3, \mathrm{H} 4, \mathrm{H} 5, \mathrm{H} 6$ and $\mathrm{H} 7$, by using the linear regression due to the significance based on the regression equations are illustrated as follows: 
Table 8: Regression results for hypotheses $\mathrm{H} 1, \mathrm{H} 2, \mathrm{H} 3, \mathrm{H} 4, \mathrm{H} 5, \mathrm{H} 6$ and $\mathrm{H} 7$

\begin{tabular}{|l|l|l|l|l|l|}
\hline No. & Variable & Beta & Sig & R Square & F change \\
\hline 1 & Trust & 0.768 & .015 & .590 & 159.405 \\
\hline 2 & Commitment & 0.950 & .224 & .902 & $1.026 \mathrm{E} 3$ \\
\hline 3 & Information sharing & 0.700 & .000 & .490 & 106.711 \\
\hline 4 & Contract completeness & 0.783 & .158 & .613 & 175.808 \\
\hline 5 & Technical capability & -0.024 & .000 & .001 & .064 \\
\hline 6 & Cultural compatibility capability & 0.792 & .003 & .627 & 186.250 \\
\hline 7 & Flexibility capability & 0.715 & .000 & .511 & 115.885 \\
\hline
\end{tabular}

The results showed that trust $(\mathrm{B}=0.768, \mathrm{t}=2.477, \mathrm{p}<.001)$, commitment $(\mathrm{B}=0.950, \mathrm{t}=1.223, \mathrm{p}<.001)$, and information sharing $(B=0.700, t=3.849, p<.001)$ were significant to the IT offshoring success. Moreover, contract completeness $(B=0.783, t=1.422, p<.001)$, cultural compatibility capability $(B=0.792, t=3.074, p<.001)$ and flexibility capability $(B=0.715, t=4.302, p<.001)$ were also significant to the IT offshoring success. While, technological capabilities $(B=-0.024, t=-.254-, \mathrm{p}<.001)$ was not

significant to IT offshoring success. The result only explained that the technological capability was not significant to the IT offshoring success. Thus, hypotheses $\mathrm{H} 1, \mathrm{H} 2, \mathrm{H} 3, \mathrm{H} 4, \mathrm{H} 6$ and $\mathrm{H} 7$ were positively related to the IT offshoring success, whereas H5 (technical capability) was negatively related to the IT offshoring success among SMEs in Iraqian. Table 8 shows the summary of hypotheses testing.

Table 8: Summary of hypotheses testing

\begin{tabular}{|l|l|l|}
\hline Hypotheses & Statement & $\begin{array}{l}\text { Accepted } \\
\text { Rejected }\end{array}$ \\
\hline Hypothesis 1: & Trust positively influences the level of IT offshoring success & Accepted \\
\hline Hypothesis 2: & commitment positively influence the level of IT offshoring success & Accepted \\
\hline Hypothesis 3: & $\begin{array}{l}\text { Information sharing is positively influence the degree of IT offshoring } \\
\text { success }\end{array}$ & Accepted \\
\hline Hypothesis 4: & contractual completeness is positively influence the level of IT offshoring success & Accepted \\
\hline Hypothesis 5: & Technological capability is positively influence the level of IT offshoring success. & Rejected \\
\hline Hypothesis 6: & Cultural compatibility is positively influence the level of IT offshoring success. & Accepted \\
\hline Hypothesis 7: & Flexibility capability is positively influence the level of IT offshoring success. & Accepted \\
\hline
\end{tabular}

\subsection{Discussion And Conclusion}

Our results show that trust and commitment across client and vendor relationship are strongly related to IT offshoring success as it is consistent with the results of Han, Lee [27]. However, this result shows that trust and commitment in relationship are not enough for successful IT offshoring arrangements at large scale, complex offshoring arrangements, information sharing within relationship also has a direct significant influence of IT offshoring success.

While we saw some highly successful enterprises use a sufficient contract standards to control their offshoring arrangements, it seems that the majority of enterprises relies on a high level of contract completeness. Thus, this research attempts to involve contract completeness as a determinant for IT offshoring. The results for contract completeness shows a highly significant influence related to IT offshoring success.

As a step to improve a strategic IT offshoring integration, capability dimension for the client enterprises has been considered within the results of this research. Three main capability factors have been tested, the technical capability is the first factor shown within these results, which illustrated insignificant influence on IT offshoring success.

Nevertheless, the results displayed that the internal technological capabilities were negatively affecting offshoring success, which denied the hypothesis in this research.

This was surprising, as some literature also indicate this artefact. The study [71], stated that when employees shared expertise, coding scheme, or specialized language, this technical strength "impedes the incorporation of outside knowledge and results in the pathology of the not-invented-here (NIH) syndrome"(p.133). Rigby and Zook [69], likewise stated that two out of five executives surveyed shows that their enterprises suffered from the NIH syndrome. 
This had affecting the willingness of enterprises to adopt external knowledge and ideas. Besides, another study indicated that the NIH syndrome was one of the obstacles for collaboration [71][72]. When an enterprise had a strong internal technical team, it could suffer the same syndrome, and not be accepted external ideas or not completely collaborate with external service providers [43, 72].

On the other hand, this findings is in contrast with other researchers such as Han, Lee [27], since they found that the firm's IT capability positively effects the information sharing level, the degree of communication quality and collaborative participation.

The Conflict between external and internal IT capabilities might decline the overall organizational IT efficiency [73], which negatively affect the offshoring project impact in turn. Offshoring organization moreover seek to improve interaction routines that maximize the intensity and frequency of sociotechnical interaction before they can have supernormal relational rents.

Furthermore, strong internal technological capabilities could help enterprises to step in and internally accomplish the project, in occasions that their service providers were not performing as expected [13].

Simply having higher technological capabilities might not be sufficient to aid offshores enjoying better knowledge share between business partners.

At contrast, cultural compatibility capability has shown highly direct significant influence on IT offshoring success. Similarly, flexibility capability for the enterprise has shown significant influence related to IT offshoring success. However, in spite of the statistical analyses, content validity is untested.

\section{CONCLUSION}

IT offshoring alternatives are a fact of modern business. For several enterprises, offshoring may be a feasible and smooth way to emphasis on core competencies, then improve the business model and accomplish important enhancements in revenue. As chances to offshore non-core operations shows themselves, nevertheless, this research highly urges a method that involve these steps that are not considered normally.

Indicating the processes benefit of tight control could aid the enterprises understanding the overall scope of the IT offshored functions and establish mechanisms for managing the IT offshoring relationship. The potential recognitions of change and defect offered by offshoring may help the enterprise not only saving money and time, but also improve the management team and the offshoring partner reputation. And, above all, communication of the offshoring decision and implementation can go a long way to smoothing the roadblocks inherent in such projects. In this research, by conducting a survey and interview, the proposed framework was presented based on the understanding and analysing of the literature review, survey, and interview. The proposed framework provides the way of enhancing the knowledge of IT offshoring in SMEs as well as the ability to identify IT offshoring potentials.

\section{REFERENCES}

1. Economic Transformation Program. 201211 November 2012

Available from: http://www.pemandu.gov.my

2. Hamzah, A.K., R. Sulaiman, and W.N. Hussein. A review on IT outsourcing approach and a proposed IT outsourcing model for Malaysian SMEs in e-Business adoption. in 2013 International Conference on Research and Innovation in Information Systems (ICRIIS). 2013. IEEE.

3. Goonetilleke, I., Identification of best practices for software outsourcing success in public sector organizations in Sri Lanka. 2012.

4. Binafikir, SMEs in the Innovation Economy- Final Report. Ministry of Science, Technology and Innovation. 2007.

5. Hamilton, L.C. and R. Asundi, Technology usage and innovation: Its effect on the profitability of SMEs. Management Research News, 2008. 31(11): p. 830-845.

6. Tan, K.S. and S.C. Chong, Internet-based ICT adoption: evidence from Malaysian SMEs. Industrial Management \& Data Systems, 2009. 109(2): p. 224-244.

7. Němcová, Z. and J. Dvořák, The Model of E-Commerce Strategy Focused on Customers. Economics and Management, 2011. 16: p. 1292-1297.

8. Carrier, B.D. and E.H. Spafford, Categories of digital investigation analysis techniques based on the computer history model. digital investigation, 2006. 3: p. 121-130. 
9. Posthumus, S. and R. Von Solms, A framework for the governance of information security. Computers \& Security, 2004. 23(8): p. 638-646.

10. Lin, C., G. Pervan, and D. McDermid, Issues and recommendations in evaluating and managing the benefits of public sector IS/IT outsourcing. Information Technology \& People, 2007. 20(2): p. 161-183.

11. Blaskovich, J. and N. Mintchik, Information technology outsourcing: A taxonomy of prior studies and directions for future research. Journal of Information Systems, 2011. 25(1): p. 1-36.

12. Sobinska, M. and L. Willcocks, IT outsourcing management in Poland-trends and performance. Strategic Outsourcing: An International Journal, 2016. 9(1): p. 60-96.

13. Mayer, K.J., Spillovers and governance: An analysis of knowledge and reputational spillovers in information technology. Academy of Management Journal, 2006. 49(1): p. 69-84.

14. Smuts, H., et al. Threats and Opportunities for Information Systems Outsourcing. in 2015 International Conference on Enterprise Systems (ES). 2015. IEEE.

15. C K, P. and G. Hamel, The core competence of the corporation. Harvard business review, 1990. 68: p. 7993.

16. Kessler, E.H., P.E. Bierly, and S. Gopalakrishnan, Internal vs. external learning in new product development: effects on speed, costs and competitive advantage. R\&D Management, 2000. 30(3): p. 213-224.

17. Johnson, G. and R. Whittington, Fundamentals of strategy with mystrategylab. 2009: Pearson Education.

18. Jaegersberg, G. and J. Ure, Barriers to knowledge sharing and stakeholder alignment in solar energy clusters: Learning from other sectors and regions. The Journal of Strategic Information Systems, 2011. 20(4): p. 343-354.

19. Hussein, W.N., R. Sulaiman, and A.K. Hamzah. E-business and cloud computing awareness for Malaysian SMEs: A recommendation from academic and industry perspectives. in 2013 International Conference on Research and Innovation in Information Systems (ICRIIS). 2013. IEEE.

20. Rahman, H., Open Innovation: Reaching out to the Grass Roots through SMEs-Exploring Issues of Opportunities and Challenges to Reach Economic Sustainability, in Human Development and Interaction in the Age of Ubiquitous Technology. 2016, IGI Global. p. 273-307.

21. Taylor, M. and A. Murphy, SMEs and e-business. Journal of Small Business and Enterprise Development, 2004. 11(3): p. 280-289.

22. Rocha, L., et al., Cloud Management Tools for Sustainable SMEs. Procedia CIRP, 2016. 40: p. 220-224.

23. Wu and C.-C. Li, E-Business Skill Demand of SMEs in Taiwan: A Comparative Study with LSEs in Japan, and USA. IERI Procedia, 2012. 2: p. 398-405.

24. Sugianto, L.F. and S. Jantavongso. eBusiness Adoption Studies Focusing on Thai SMEs. in Computational Intelligence for Modelling, Control and Automation, 2006 and International Conference on Intelligent Agents, Web Technologies and Internet Commerce, International Conference on. 2006. IEEE.

25. Wu, M. and L. Zhang. A Study for Understanding E-Commerce Adoption in China's Service SMEs from Web Usability Perspective. in Wireless Communications, Networking and Mobile Computing, 2007. WiCom 2007. International Conference on. 2007. IEEE.

26. Wimmer, M.A., K. Bogataj, and A. Pucihar, Research themes and roadmap charts. 2007.

27. Han, H.-S., J.-N. Lee, and Y.-W. Seo, Analyzing the impact of a firm's capability on outsourcing success: A process perspective. Information \& Management, 2008. 45(1): p. 31-42.

28. Saleh, A.S. and N.O. Ndubisi, An evaluation of SME development in Malaysia. International Review of Business Research Papers, 2006. 2(1): p. 1-14.

29. Marimuthu, M., A. Omar, and T. Ramayah, Readiness to Adopt E-Business Among SMEs in Malaysia: Antecedents and Consequence. International Journal of E-Adoption (IJEA), 2011. 3(3): p. 1-19.

30. Vasiliauskiene, L. and V. Snieska, Evaluation of outsourcing Models determining the variation of transaction costs. Economics and Management, 2011. 16: p. 428-436.

31. Cullen, S. and L. Willcocks, Intelligent IT outsourcing: eight building blocks to Success. Oxford: Butterworth-Heinemann. 2003.

32. Abdolvand, N., Effects of human factor on the success of Information technology outsourcing. arXiv preprint arXiv:1603.04620, 2016.

33. Lane, M.S. and W.H. Lum, Examining client perceptions of partnership quality and its dimensions in an IT outsourcing relationship. Australasian Journal of Information Systems, 2010. 17(1): p. 47-76.

34. Hamzah, A.K., A Review of IT Outsourcing Relevant and Success Determinants and A Proposed Model. Journal of Advanced Computer Science and Technology Research, 2013. 3(3): p. 136-152.

35. Swar, B., et al., Determinants of relationship quality for IS/IT outsourcing success in public sector. Information Systems Frontiers, 2012. 14(2): p. 457-475. 
36. Goo, J. and C.D. Huang, Facilitating relational governance through service level agreements in IT outsourcing: an application of the commitment-trust theory. Decision Support Systems, 2008. 46(1): p. 216232.

37. Lee, J.-N., M.Q. Huynh, and R. Hirschheim, An integrative model of trust on IT outsourcing: Examining a bilateral perspective. Information Systems Frontiers, 2008. 10(2): p. 145-163.

38. Goo, J., C.D. Huang, and P. Hart, A Path to Successful IT Outsourcing: Interaction Between Service-Level Agreements and Commitment. Decision Sciences, 2008. 39(3): p. 469-506.

39. Handley, S.M. and W. Benton Jr, Unlocking the business outsourcing process model. Journal of Operations Management, 2009. 27(5): p. 344-361.

40. Blumenberg, S., D. Beimborn, and W. Koenig. Determinants of IT outsourcing relationships: a conceptual model. in Hawaii International Conference on System Sciences, Proceedings of the 41st Annual. 2008. IEEE.

41. Hamid, N.A.A. and R. Suberamany, IT/IS Outsourcing Relationship Factors in Higher Education Institution: Behavioral Dimensions from Client Perspectives. World Academy of Science, Engineering and Technology, 2009. 50: p. 813-822.

42. Luftman, J., C.V. Brown, and S. Balaji, Customer-Provider Strategic Alignment: A Maturity Model, in Service Systems Implementation. 2011, Springer. p. 145-163.

43. Chan, S.K.-L., Governance methods used in externalizing information technology. 2012, Cleveland State University.

44. Gellings, C. Outsourcing Relationships: The Contract as IT Governance Tool. in System Sciences, 2007. HICSS 2007. 40th Annual Hawaii International Conference on. 2007. IEEE.

45. Kang, M., et al., Aligning organizational control practices with competitive outsourcing performance. Journal of Business Research, 2012. 65(8): p. 1195-1201.

46. Han, H.-S., et al., Complementarity between Client and Vendor IT Capabilities: An Empirical Investigation in IT Outsourcing Projects. Decision Support Systems, 2013.

47. Ndubisi, N.O., Conflict handling, trust and commitment in outsourcing relationship: A Chinese and Indian study. Industrial Marketing Management, 2011. 40(1): p. 109-117.

48. Earl, M.J., The risks of outsourcing IT. Sloan management review, 2012. 37(3).

49. Sulaiman, R., S. Shariff, and M. Ahmad. Applying a multi-method approach in exploring e-Business potential for home-based businesses in Malaysia. in Information Technology, 2008. ITSim 2008. International Symposium on. 2008. IEEE.

50. Ravichandran, T. and C. Lertwongsatien, Effect of information systems resources and capabilities on firm performance: A resource-based perspective. Journal of Management Information Systems, 2005. 21(4): p. 237-276.

51. Mudambi, S.M. and S. Tallman, Make, buy or ally? Theoretical perspectives on knowledge process outsourcing through alliances. Journal of Management Studies, 2010. 47(8): p. 1434-1456.

52. Kalid, N., et al., Based real time remote health monitoring systems: A review on patients prioritization and related" big data" using body sensors information and communication technology. Journal of medical systems, 2018. 42(2): p. 30.

53. Lee, J.-N., The impact of knowledge sharing, organizational capability and partnership quality on IS outsourcing success. Information \& Management, 2001. 38(5): p. 323-335.

54. Mellewigt, T., A. Madhok, and A. Weibel, Trust and formal contracts in interorganizational relationshipssubstitutes and complements. Managerial and Decision Economics, 2007. 28(8): p. 833-847.

55. Kalid, N., et al., Based on real time remote health monitoring systems: a new approach for prioritization "large scales data" patients with chronic heart diseases using body sensors and communication technology. Journal of medical systems, 2018. 42(4): p. 1-37.

56. Salman, O.H., et al., Novel methodology for triage and prioritizing using "big data” patients with chronic heart diseases through telemedicine environmental. International Journal of Information Technology \& Decision Making, 2017. 16(05): p. 1211-1245.

57. Jumaah, F., et al., Decision-making solution based multi-measurement design parameter for optimization of GPS receiver tracking channels in static and dynamic real-time positioning multipath environment. Measurement, 2018. 118: p. 83-95.

58. Grover, V., M.J. Cheon, and J.T. Teng, The effect of service quality and partnership on the outsourcing of information systems functions. Journal of Management Information Systems, 1996. 12(4): p. 89-116.

59. Sung, W.-T. and K.-Y. Chang, Evidence-based multi-sensor information fusion for remote health care systems. Sensors and Actuators A: Physical, 2013. 204: p. 1-19. 
60. Zhong, F. and M.D. Myers, CLIENT-VENDOR RELATIONSHIPS IN CLOUD COMPUTING: LESSONS FROM IT OUTSOURCING. 2016.

61. Martin, S.F., H.-T. Wagner, and D. Beimborn, Process documentation, operational alignment, and flexibility in IT outsourcing relationships: A knowledge-based perspective. 2008.

62. Salman, O., et al., Novel methodology for triage and prioritizing using "big data" patients with chronic heart diseases through telemedicine environmental. International Journal of Information Technology \& Decision Making, 2017. 16(05): p. 1211-1245.

63. Wang, J.-J. and D.-L. Yang, Using a hybrid multi-criteria decision aid method for information systems outsourcing. Computers \& Operations Research, 2007. 34(12): p. 3691-3700.

64. Fisher, C.M., Researching and writing a dissertation: a guidebook for business students. 2007: Prentice Hall.

65. Bless, C. and Higson-Smith, Fundamentals of social research methods: An African perspective. 2006: Juta and Company Ltd.

66. SMIDEC. Small and Medium Industries Development Corporation 201315 February, 2013]; Available from: http://www.smecorp.gov.my/vn2/.

67. Mao, J.-Y., J.-N. Lee, and C.-P. Deng, Vendors' perspectives on trust and control in offshore information systems outsourcing. Information \& Management, 2008. 45(7): p. 482-492.

68. Eisingerich, A.B. and S.J. Bell, Perceived Service Quality and Customer Trust Does Enhancing Customers' Service Knowledge Matter? Journal of service research, 2008. 10(3): p. 256-268.

69. Rigby, D. and C. Zook, Open-market innovation. Harvard business review, 2002. 80(10): p. 80-93.

70. Sekaran, U., Research methods for business: A skill building approach. 2006: Wiley. com.

71. Jasim, M.H., et al., Emotion Detection among Muslims and Non-Muslims While Listening To Quran Recitation Using EEG. International Journal of Academic Research in Business and Social Sciences, 2019. 9(14): p. 10-16.

72. Hamzah, A., et al., A Review on Triaging For Patients in the Emergency Department: Overview, Aims, Guideline, and Challenges. 2019.

73. Nevo, S., M.R. Wade, and W.D. Cook, An examination of the trade-off between internal and external IT capabilities. The Journal of Strategic Information Systems, 2007. 16(1): p. 5-23. 